\title{
FAKTOR-FAKTOR YANG BERPENGARUH TERHADAP CEMARAN AIR MINUM ISI ULANG OLEH ESCHERICHIA COLI DI KOTA DENPASAR TAHUN 2015
}

\author{
Sabariah \\ Fakultas Kedokteran Universitas Islam Al-Azhar \\ Jl. Unizar No.20 Turida Mataram \\ hussabariah@yahoo.co.id
}

\begin{abstract}
ABSTRAK
Drinking water is water that meets quality of health. The requirements include microbiology, chemistry, physics and radioactivity aspects. The high public interest in the consumption of bottled water and high prices of bottled drinking water encourage. However, the growth of refill drinking water (AMIU), licensing, training, supervision and circulation can not be done properly, which affect the poor drinking water quality assurance that could potentially cause harm to health.The study was a analytical descriptive study with cross sectional. This study showed 7 (15.6\%) of 45 refilled drinking water were contaminated with E.coli. The factors that were not related with E.coli contamination were raw water $(\mathrm{p}=0.181>0.05)$, the disinfectant $(\mathrm{p}=0.368)$ and sanitary facilities $(\mathrm{p}=0.771)$. However, it was related with sanitary location $(\mathrm{p}=0.000)$.Factors associated with E.coli contamination in drinking water refilled depot in Denpasar city.
\end{abstract}

Kata Kunci: DAMIU, E.coli, Denpasar, Sanitation, Raw Water.

\section{PENDAHULUAN}

Air minum adalah air yang kualitasnya memenuhi syarat kesehatan dan dapat langsung diminum, syarat kesehatan yang dimaksud adalah mikrobiologi, kimia fisika dan radio aktif.Air di dalam tubuh manusia,berkisar antara 50-70\% dari berat badannya.Untuk orang dewasa memerlukan air 1,5 liter setiap hari. Pentingnya air bagi kesehatan dapat dilihat dari jumlah air yang ada dalam organ, seperti $80 \%$ dari darah adalah air, kehilangan 15\% dari berat badan dapat mengakibatkan kematian.

Dalam memenuhi kebutuhan air, manusia selalu memperhatikan kualitas dan kuantitas air. Kualitas yang cukup diperoleh dengan mudah karena adanya siklus hidrologi, yakni siklus ilmiah yang mengatur dan memungkinkan tersedianya air permukan dan air tanah. Namun demikian, pertumbuhan penduduk dan kegiatan manusia menyebabkan pencemaran sehingga kualitas air yang baik dan memenuhi persyaratan tertentu sulit diperoleh. Hal inilah yang menjadi alasan mengapa air minum dalam kemasan (AMDK) yang disebut-sebut menggunakan air pengunungan banyak dikonsumsi.

Depot air minum adalah usaha yang melakukan pengolahan air baku menjadi air minum dan menjual langsung kepada konsumen. Dampak positif adanya depot air minum adalah menyediakan air minum yang kualitasnya aman dan sehat bagi konsumen, menyediakan air minum yang memenuhi kuantitas dan menyediakan air minum 
secara kontinyu untuk menunjang kebutuhan rumah tangga. Disisi lain, perkembangan depot air minum berpotensi menimbulkan dampak negatif apabila tidak adanya regulasi yang efektif. Isu yang mengemuka saat ini adalah rendahnya jaminan kulitas air minum yang dihasilkan.sehingga apabila hal tersebut tidak dikendalikan akan menyebabkan kerugian bagi kesehatan misalnya keracunan zat kimia dan penyebaran penyakit melalui air.

Masalah yang muncul akibat rendahnya mutu pengawasan adalah banyaknya depot air minum yang tidak memenuhi syarat kesehatan. Persyaratan yang dimaksudyaitu dalam air minum tidak boleh ada kandungan E.coli dan coliform. Pada umumnya AMDK telah mendapat ijin usaha, peredaran dan pengawasan AMDK telah mendapat izin dari instansi terkait sebelum diedarkan. Namun, harga AMDK dari berbagai merek yang terus meningkat membawa konsumen mencari alternatif baru yang murah. Tingginya minat masyarakat dalam mengkonsumsi AMDK dan mahalnya harga AMDK mendorong tumbuhnya depot air minum isi ulang diberbagai tempat terutama di kota-kota besar. Dilihat dari segi harganya air minum isi ulang lebih murah bila dibandingkan dengan AMDK akan tetapi masyarakat masih ragu dalam menentukan kualitasnya karena air minum isi ulang (AMIU) mengenai perizinan, pembinaan, pengawasan dan peredarannya belum dapat dilakukan sebagai mana mestinya padahalmasyarakat memerlukan informasi yang jelas terutama tentang keamanan konsumsi. sehingga aman untuk dikonsomsi.

Masyarakat sebagai konsumen air minum perlu dilindungi haknya, seperti yang tertulis dalam tentang perlindungan kosumen. Bahwa konsumen memiliki hak atas kenyamanan, keamanan dan keselamatan dalam mengkonsumsi barang atau jasa dan hak atas informasi yang benar, jelas dan jujur mengenai kondisi dan jaminan barang atau jasa. Ada beberapa kemungkinan penyebab DAMIU terkontaminasi diantaranya sumber air baku, wadah tempat distribusi tidak memenuhi standard hygiene dan sanitasi DAMIU, juga proses filtrasi dan desinfektan dengan teknologi yang rendah. Higiene Sanitasi adalah upaya untuk mengendalikan faktor risiko terjadinya kontaminasi yang berasal dari tempat, peralatan dan penjamah terhadap Air Minum agar aman dikonsumsi. Penelitian terhadap populasi DAMIU di Semarang ditemukan 34\% depot tercemar bakteri. Demikian juga dengan hasil penelitian di Kota Bogor terhadap 27 depot ditemukan 2 (7\%) depot tercemar bakteri. Hasil Sidak Dinas Kesehatan Jakarta Barat pada Januari 2009 yang lalu menemukan 384 sampel dari DAMIU yang tercemar 
E.coli. Hasil Pengujian kualitas 120 sampel DAMIU dari 10 kota besar (Jakarta, Bogor, Tangerang, Bekasi, Cikampek, Semarang, Yogyakarta, Surabaya, Medan dan Denpasar).Sekitar 16\% dari sampel tersebut terkontaminasi bakteri coliform hal ini menunjukkan buruknya kualitas depot air minum isi ulang.

Berdasarkan hasil uji petik pengambilan sampel depot air minum pada tahun 2013 oleh Dinas Kesehatan Provinsi Bali di sembilan Kabupaten/Kota, sebanyak $20 \%$ sampel air minum isi ulang dinyatakan tidak memenuhi persyaratan bakteriologis. Penelitian yang pernah dilakukan oleh Partiana pada tahun 2015 terhadap Kualitas bakteriologis air minum isi ulang di Kabupaten Badung di ketahui bahwa sebesar $88,9 \%$ air minum isi ulang memenuhi sayarat dan $11,1 \%$ tidak memenuhi sayarat karena mengandung bakteri E.coli dan Coliform.

Berdasarkan hasil beberapa penelitian diberbagai daerah ditemukan pola pembinaan dan pengawasan terkait dengan perijinan usaha, pengolahan dan hygiene sanitasi depot air minum belum jelas, serta masih banyak kandungan kuman dan bakteri dalam air mium isi ulang. Dengan semakin banyaknya depot air minum yang bermunculan, dan demi untuk melindungi konsumen ataupun masyarakat yang menggunakan air minum isi ulang sebagai alternatif yang murah dalam memenuhi kebutuhan air minum, maka berdasarkan pertimbangan tersebut diatas perlu dilakukan penelitian tentang faktor-faktor yang berpengaruh terhadap cemaran air minum isi ulang oleh bakteri E. coli di Kota Denpasar.

\section{METODELOGI PENELITIAN}

Penelitian ini adalah penelitian dengan pendekatan cross sectional analitik.Prosedur pengambilan sampel menggunakan metodesimple random samplin.

Pemeriksaan E.Coli pada Air Minum Isi Ulang.

Dalam pemeriksan makanan dan minuman keberadaan $E$ coli dan bakteri berbahaya (Patogen) harus 0 koloni/ml untuk sampel minuman. Mengacu pada tentang persyaratan kualitas air bersih.

\section{Prosedur Kerja Pengukuran E.coli}

Presumptive Tes : $10 \mathrm{ml}$ sampel air dipipet dan dimasukkan dalam masingmasing lima tabung yang berisi Lactose Broth yang didalamnya terdapat tabung durham terbalik $1 \mathrm{ml}$ sampel air dipipet dan dimasukkan dalam masing-masing lima tabung yang berisi Lactose Broth yang didalamnya terdapat tabung durham terbalik.0,1 $\mathrm{ml}$ sampel air dipipet dan dimasukkan dalam masing-masing lima tabung yang berisi Lactose Broth yang didalamnya terdapat tabung durham 
yang lebih banyak untuk memperoleh air yang siap untuk dikonsumsi.

Berdasarkan hasil penelitian dan pengamatan sumber air baku yang digunakan pada air minum isi ulang di Kota Denpasar adalah sumur bor dan sumber mata air dimana air minum isi ulang yang menggunakan sumber air baku dari mata air sejumlah (82,2\%), yang positif E.coli sebanyak $(15,6 \%)$ dan colifrom sebanyak $(37,8 \%)$. sedangkan yang menggunakan sumber air baku dari sumur bor sejumlah $(17,6 \%)$, hanya terdapat colifrom sebanyak $(8,9 \%)$ pada air minum isi ulang. Hal ini disebabkan oleh adanya kontaminasi pada peralatan pengolahan air minum, pengetahuan akan higienis operator penjamah atau pemilik depot masih kurang. Sanitasi tempat pengolahan air minum. Waktu penyimpanan air, dan tidak optimalnya sistem disinfektan atau sterilisasi.

Di Kota Denpasar pelatihan dan sertifikat untuk operatur DAMIU masih sangat minim yaitu dari 45 sampel, sebanyak $80 \%$ tidak pernah mengikuti kursus higienis sanitasi dan sebanyak $20 \%$ sudah mengikuti kursus higienis sanitasi. Pengetahuan merupakan variabel confounding terhadap kualitas disinfektan, sanitasi, kebersihan dan tingkah laku operator. Peningkatan pengetahuan dapat dilakukan dengan melaksanakan kursus kebersihan sanitasi
DAM dan pendidikan atau penyuluhan kesehatan kepada operator yang disertai sertifikat sebagai bukti telah mengikuti kursus kebersihan sanitasi. Penyimpanan air baku lebih dari 3 hari dapat menurunkan kualitas air minum yang dihasilkan. Penelitian lain menyatakan bahwa penyimpanan air baku yang terlalu lama (lebih dari 3 hari) dapat berpengaruh terhadap kualitas air minum yaitu menimbulkan

pertumbuhan mikroorganisme.

Disamping itu juga sebanyak $80 \%$ DAMIU tidak memiliki surat keterangan laik higienis sanitasi karena berdasarkan hasil wawancara dengan pengurus ASDAM tidak ada tuntutan dari pihak pemerintah terkait untuk mempunyai surat keterangan laik higienis sanitas sebagai syarat untuk memiliki usaha DAMIU. DAM dikatakan memenuhi standar baku mutu atau persyaratan kualitas air minum dan syarat higienis sanitasi apabila mempunyai bukti tertulis yang dikelurkan oleh dinas kesehatan kabupaten/kota setempat. Dengan terdaftarnya suatu usaha maka usaha tersebut sudah berbadan hukum, sehingga masyarakat atau konsumen lebih percaya dengan pelaku usaha yang memiliki kapasaitas dimata humum. Selain itu tidak hanya pelaku usaha yang menerima manfaatnya akan tetapi pada dasarnya ada 3 pihak yang memperoleh manfaat dari 
perusahan, yaitu pemerintah, pelaku usaha dan masyarakat umum atau konsumen.

Hubungan Proses Desinfektan dengan Cemaran E.coli pada Air Minum Isi Ulang di Kota Denpasar

Tabel 3. Hubungan Desinfektan Dengan Cemaran E.coli pada Air Minum Isi Ulang Tahun.

\begin{tabular}{lccccccc}
\hline \multicolumn{2}{c}{ Desinfektan } & & Cemaran E.coli & & Total \\
$\mathrm{p}$ & $\mathrm{X}^{2}$ & & & & & \\
& & & & & & \\
& & Positif & \multicolumn{2}{c}{ Negatif } & & \\
& $\mathrm{N}$ & $\%$ & $\mathrm{~N}$ & $\%$ & $\mathrm{~N}$ & $\%$ \\
\hline RO & 0 & 0 & & 4 & 8,89 & 4 \\
& 8,89 & & & & \\
& & 0,368 & 0,89 & & &
\end{tabular}

$\begin{array}{llllll}\text { Ultraviolet } \quad 7 & 15,6 & 34 & 75,6 & 41\end{array}$ 88,9

Bedasarkan hasil penelitian yang dilakukan dengan ujichi square $\mathrm{P}=0,368$ $(\mathrm{P}>0,05)$ artinya bahwa tidak ada hubungan yang bermakna antara cemaran E.coli dengan proses desinfektan pada air minum isi ulang di Kota Denpasar.

Proses pengolahan pada air minum isi ulang di Kota Denpasar umumnya memenuhi syarat karena berdasarkan bahwa peralatan sterilisasi / desinfektan harus ada pada sebuah depot air minum, dapat berupa ultraviolet atau Ozoniasi atau peralatan lainnya atau bisa lebih dari satu, yang masih berfungsi.
Namun pada kondisi peralatan tertentu dalam proses pengolahan air, jika tidak ada masa pakai dari alat yang digunakan maka akan mengurangi kinerja terhadap alat tersebut.

Jumlah coliform dalam air disebabkan oleh desinfektan yang tidak sempurna serta pencucian dan pembilasan galon yang rawan pencemaran. Faktor lain yang dapat mempengaruhi kualitas air hasil produksi adalah air baku, jenis peralatan yang digunakan, pemeliharaan peralatan dan penanganan pengolahan dan pendistribusian air.

Sebagian besar air minum isi ulang di Kota Denpasar menggunakan Ultraviolet sebagai alat desinfektan, namun masa kerja Ultraviolet dan panjang gelombang Ultraviolet tidak diketahui dengan pasti karena tidak dilakukan pengukuran, penilaianya hanya berdasarkan wawancara dan observasi keberadaan alat dan masih menyala atau tidak lampu indikatornya. Pada Ultraviolet yang menjadi indikator adalah lampu merah dan biru. Jika tombol on ditekan kemudian tidak menyala berarti lampu Ultraviolet harus diganti.

Penggunan Ultraviolet yang tidak sesuai antar kapasitas dan kecepatan air yang melewati penyinaran ultraviolet, sehingga air terlalu cepat, maka bakterinya tidak mati. Idealnya, untuk air minum kapasitas ultraviolet minimal adalah tipe 8 GPM 
(galon permenit) berarti kran pengisian depot digunakan untuk mengisi maksimal 1,5 botol per menitnya.

Semakin lama air baku kontak dengan alat desinfektan, maka semakin tinggi kesempatan alat desinfektan menyinari air baku yang menyebabkan matinya mikroba.

Keberadan izin atau rekomendasi filter dan mikrofilter termasuk didalamnya pencatuman masa kerja filter dan mikrofilter turut berpengaruh bagi cemaran mikroba pada air minum isi ulang. Masa pakai dari mikro filter sudah ditentukan oleh produsen (pabrik yaang membuat) mikro filter. Semakin lengkap ukuran filter yang digunakan (10-0,1 mikron) maka filter tersebut dapat menyaring bakteri ataupun partikel-partikel halus lain yang ada di dalam air. Umumnya sebagai indikator penggantian mikrofilter adalah kondisi mikrofilter yang sudah kotor yang meninggalkan warna coklat atau hitam pada filter.

Menurut penelitian di Kecamatan Tanjung Pinang Barat menunjukan alat yang gunakan tidak dalam masa pakai atau filter yang digunakan tidak bertingkat merupakan beberapa faktor di temukannya bakteri E.coli pada air minum isi ulang.

Tabel 4. Hubungan Sanitasi Dengan Cemaran E.coli pada Air Minum Isi Ulang DI Kota Denpasar.

\begin{tabular}{|c|c|c|c|c|c|c|}
\hline \multirow{4}{*}{$\begin{array}{r}\text { Sanitasi } \\
\mathrm{X}^{2}\end{array}$} & \multirow{4}{*}{\multicolumn{2}{|c|}{ Kondisi }} & \multicolumn{4}{|c|}{ Cemaran E.coli } \\
\hline & & & & & & \\
\hline & & & \multicolumn{2}{|c|}{ Positif } & \multicolumn{2}{|c|}{ Negatif } \\
\hline & & & $\mathrm{N}$ & $\%$ & $\mathrm{~N}$ & $\%$ \\
\hline LokasiMS & & 0 & 0 & 3 & & ,3 \\
\hline \multicolumn{2}{|c|}{0,000} & 22 & 796 & & & \\
\hline \multicolumn{2}{|c|}{ TMS } & 7 & 15, & & \multicolumn{2}{|c|}{11,1} \\
\hline \multirow{2}{*}{$\begin{array}{l}\text { Fasilitas } \\
\text { Sanitasi }\end{array}$} & \multicolumn{2}{|c|}{$\mathrm{MS}$} & \multicolumn{2}{|c|}{10,02} & 4 & 0,08 \\
\hline & & & & & & 0,771 \\
\hline \multicolumn{7}{|l|}{0,085} \\
\hline & \multicolumn{2}{|c|}{ TMS } & 6 & 0,13 & 34 & 0,75 \\
\hline
\end{tabular}

Hubungan Sanitasi Lokasi dengan Cemaran E.Coli Pada Air Minum Isi Ulang Pada Depot Air Minum Isi Ulang Di Kota Denpasar.

Berdasarkan hasil penelitian lokasi DAMIU di Kota Denpasar sebagian besar berada di perumahanpemukiman padat penduduk, pinggir jalan raya dan dipertokoan, sehingga sebagian besar lokasinya dekat dengan pencemaran misalnya bercampur dengan usaha laundry, bengkel, Las, dan jualan sembakao. Sanitasi lingkungan yang tidak memadai merupakan sumber potensi kontaminasi air minum.

Dari 45 sampel terdapat 73, 3\% air minum isi ulang memenuhi syarat dan $11,1 \%$ tidak memenuhi syarat. Secara statistik menunjukan ada hubunagan yang bermakna antara kebersihan lokasi kerja 
dengan cemaran E.coli. Hal ini dapat dijelaskan dari hasil analisis bivariat dengan nilai chi square adalah 22,796 dengan nilai $\mathrm{p}=0,000(\mathrm{p}<0,05)$.

Hasil penelitian semakin tinggi kualitas kebersihan, maka kualitas air minum isi ulang semakin baik. Hasil penelitian ini sesuai dengan penelitian di Semarang yang menyatakan $(\mathrm{p}=0,0001)$ yang berarti bahwa ada hubungan yang bermakna antara kondisi sanitasi air minum isi ulang dengan kualitas bakterologi. Hal ini membuktikan bahwa lingkungan kerja berpengaruh terhadap mutu air minum isi ulang khususnya lokasi kerja.

Penelitian sejenis juga menunjukan didaerah lain belum semua DAMIU menerapkan higienis sanitasi seperti pada penelitian di Kota Medan 20\% DAMIU dan di Wonogiri 22,2\% DAMIU tidak memenuhi syarat higienis sanitasi. Dikedua daerah tersebut miliki kesamaan dengan lokasi penelitia yaitu belum ada peraturan daerah yang mewajibkan higienis sanitasi menjadi salah satu syarat dalam mendirikan usaha DAMIU dan tidak ada pengawasan dari dinas terkait dalam menjaga agar DAMIU tetap menjadi higienis sanitasi untuk memenuhi persyaratan yang ada.

\section{Hubungan Fasilitas Sanitasi dengan Cemaran E.colipada Air Minum Isi Ulang di Kota Denpasar.}

Berdasarakan hasil penelitian pada air minum isi ulang di Kota Denpasar fasilitas sanitasi yang tidak memenuhi syarat sebanyak $88,9 \%$. Secara statistik menunjukan tidak ada hubungan yang bermakana antara fasilitas sanitasi dengan cemaran E.coli.. Tangan operator adalah titik kritis, cara pengendalianya adalah dengan melakukan cuci tangan menggunakan sabun sebelum melayani pembeli sehingga tidak terjadi kontaminasi.

Pada prinsipnya pencucian tangan dilakukan setiap saat, setelah menyentuh benda-benda yang dapat menjadi sumber kontaminasi atau cemaran ${ }^{8}$ Menurut penelitian ${ }^{26}$ di ketiga wilayah yaitu di Aceh Besar, Nias dan Simeulue, didapatkan > 60 $\%$ orang yang diamati menggunakan sabun saat mencuci tangan.

\section{KESIMPULAN}

Berdasarkan hasil penelitian faktorfaktor yang berpengaruh terhadap cemaran air minum isi ulang oleh bakteri E. coli di Kota Denpasar tahun 2015 dapat disimpulkan sebagai berikut : Sebanyak 7 AMIU (15,6\%) DAMIU di Kota Denpasar tercemar E. coli.Faktor yang berhubungan dengan cemaran E. coli pada air minum isi ulang di Kota Denpasar adalah sanitasi lokasi $(\mathrm{p}=0,000<0,05)$.Faktor yang tidak memiliki hubungan dengan cemaran E.coli 
pada air minum isi ulang di Kota Denpasar adalah air baku $(\mathrm{p}=0,181>0,05)$, proses disinfektan $\quad(p=0,368>0,05), \quad$ fasilitas sanitasi $(\mathrm{p}=0,771>0,05)$.

\section{UCAPAN TERIMA KASIH}

Melalui kesempatan ini penulis mengucapkan terimaksih yang sebesarbesarnya kepada :

Dr. dr. I Dewa Made Sukrama, Msi., SpMK (K), Selaku Pimbimbing I yang telah memberikan petunjuk, arahan, dan bimbingan bagi penulis selama menempuh pendidikan Magisterdandr. Ni Nengah Dwi Fatmawati, SpMK., Ph.D selaku pembimbing II yang dengan sabar dan ihlas meluangkan waktu untuk membimbing penulis selama proses penyelsaian tulisan ini.

\section{DAFTAR PUSTAKA}

Anonim, 1999. Undang-undang No.8/1999. Perlindungan Konsumen; Undangundang Republik Indonesia.

Anonim, 2004. Diadopsi dari Keputusan Mentri Perindustrian dan Perdagangan RI No. 651/MPP/Kep/10/2004 tentang persyaratan teknis dept air minum dan perdagangannya dan pedoman pelaksanaan Penyelengaraan higienis sanitasi pengawasan higienis sanitasi depot air minum.Ditjen P2PL DepKes RI.

Anonim. 2002. Keputusan Menteri Kesehatan RI. No. 907/Menkes /SK/ VII/2002 tentang Syarat-syarat dan
Pengawasan Kualitas Air Minum. Departemen Jakarta : Kesehatan Republik Indonesia.

Anonim. 2004, Keputusan Menteri Perindustrian dan Perdagangan No. 651/MPP/Kep/10/2004, tentang Persyaratan Teknis Depot Air Minum dan Perdagangan. Kementrian Perindustrian danPerdagangan Republik Indonesia.

Anonim. 1990. Keputusan Menteri Kesehatan No. 416/Menkes /Per/IX/1990 tentang Syarat-syarat dan Pengawasan Kualitas Air. Peraturan Menteri Kesehatan Republik Indonesia.

Anonim. 2014. Peraturan Menteri Kesehatan RI No. 43 Higienis Sanitasi Depo Air Minum. Menteri Kesehatan Republik Indonesia.

Departemen Kesehatan RI, 2010. Peraturan Menteri Kesehatan No. 492/MENKES/PER/IV/2010 tentang Kualitas Air Minum. Jakarta Dis. [2016 Mei 17]. Available from : https://www.google.com.

Asfawi, S.2004. Analisis faktor yang berhubungan dengan kualitas bakteriologis air minum isi ulang pada tingkat produsen di Kota Semarang [tesis]. Semarang: Universitas Diponegoro.

Athena, Sukar, M. Hendro. Anwar, dan Hariono, M.D, 2004. Kandungan, Pb, $\mathrm{Cd}, \mathrm{Hg}$ dalam Air Minum dari Depot Air Minum Isi Ulang di Jakarta, Tangerang, Dan Bekasi. Jurnal Ekologi Kesehatan. 3(3): 148-152

Badan Pengawas Obat dan Makanan RI. 2008. Pengujian Mikrobiologi Pangan. Infopom. 9(2): 3

Badan Perlindungan Konsumen Indonesia 2010, SNI wajib air minum dalam kemasan. Jakarta : Badan Perlindungan Konsumen Indonesia. 
Chemulity, J.K., Gatura, P.B., Kyule, M.M., Njeruh, M.M. 2002. Bacteriological qualities of indoor and out-door drinking water in Kibera sub-location in Nairobi. Kenya. East African Medical Journal. [cited 2015 Jan 08]; 79 (5):271-3. Avalaible from : http://www.ajol.info/index. php/ eamj/ article/ view/8868/1821

Dahlan, M.S. 2010. Besar Sampel dan Cara Pengambilan Sampel Dalam Penelitian Kedokteran dan Kesehatan. Edisi 3. Jakarta : Salemba Mardika.

Ferawaty, E. 2003, Study Identifikasi Eschericia Coli pada Air Minum Isi Ulang Tingkat Produsen di Kota Semarang. Universitas Diponegoro.

Hamidin, A.S. 2012. Kemampuan Terapi Air Putih Untuk Penyembuhan, Diet, Kehamilan, dan Kecantikan. Jakarta :MedPress (Anggota IKAPI). P (27).

Irianrto, K. 2006. Mikrobiologi Menguak Dunia Mikroorganisme. Edisi pertama. Margahayu Pemai Bandung. Yramada Widya. P 10-11.

Jawetz, et al. 2015. Medical Microbiology. 27th. New York: McGraw-Hill. P. 231-235.

Khiki, P.K, Onny, S. Nur, W.E. 2014. Faktor-faktor yang Berhubungan dengan Cemaran Mikroba dalam Air Minum Isi Ulang pada Depot Air Minum Kota Makasar. Jurnal Kesehatan Lingkungan Indonesia. 13(2).

Luuk, 2008. Integratet Simulation of drinking water Treatment. Jurnal of Water. Supply (57) : 133-141.

Mirza, N.M. 2014. Hygeine sanitasi dan jumlah colifrom air minum. Jurnal Kesehatan Masyarakat. 9(2): 167173.

Partiana, I.M. 2015. Kualitas Bakteriologi Air Minum Isi Ulang pada Tingkat
Produsen di Kabupaten Badung (Tesis). Denpasar. Universitas Udayana.

Pratiwi, A.W. 2007. KualitasBakteriologis Air Minum Isi Ulang di Wilayah Kota Bogor.Jurnal Kesehatan Masyarakat Nasional, 2(2).

Prihartini, R. 2012. Kualitas Air Minum Isi Ulang pada Depot Air Minum di Kabupaten Bogor (Skripsi). Jakarta. Universitas Indonesia.

Rolan, S.P. Intje, P. Mahayasa, I.N.W. 2013. Cemaran Mikroba Escherichia coli dan Total Bakteri Koliform pada Air Minum Isi Ulang. Emerg. Infect. Dis. [cited 2016 Mei. 10]. Available from: URL: http :/www. cdc. gov. /ncidod/ EID/eid.htm.

Siwanto, Susila dan Suyanto,. 2013. Metodelogi Penelitian Kesehatan dan Kedokteran. Yogyakarta : Bursa Ilmu. P (80).

Sundeep, K.G. Suantio, A., Gray, A., Widiastuti, E., Jain, N., Rolos, R., Robert, M.H., dan Quick, R. 2007. Factors associated withe. Colicontamination of household Drinking water among tsunami and earthquake Survivors, indonesia. Am. J. Trop. Med. Hyg., 76(6), 2007, pp. 1158-1162.

Sutrisno, T.C., Eni, S. 1997. Teknologi Penyediaan Air Bersih. Jakarta: Reneka Cipta. P (65).

Suprihatin. 2003. Sebagian Air Minum Isi Ulang Tercemar Bakteri Coliform.Tim Penelitian Laboratorium Teknologi dan Manajemen lingkungan. IPB: Kompas, 26 April.

Sri Malem, I. 2008. Analisis higienis sanitasi dan kualitas air minumisi ulang berdasarkan sumber air di Kota Medan. (Tesis). Universitas Sumatra Utara. 
Veronika, A.S, Devi, N.S., Taufik, A. 2012.

Pelaksanaan Hygiene Sanitasi Depot dan Pemeriksaan Kandungan Bakteri Escherichia coli pada Air Minum Isi Ulang di Kecamatan Tanjung Pinang Barat Tahun 2012. Fakultas Kesehatan Masyarakat, Universitas Sumatera Utara. [cited 2016 Mei. 10]. Available from: URL: http :/www. cdc. gov. /ncidod/ EID/eid.htm.

Wartawarga. 2011. Hukum Dagang Wajib Daftar Perushaan dan Hak Kekayaan Intelektual. Dis. 8 Mei 2016. Available from: http://wartawarga.gunadarma.ac.id/2 011/05/hukum-dagang-wajib-daftarperusahaan-dan-hak-kekayaanintelektual.

WHO, 2011. Pedoman kualitas air minum. (serial online), Juni., [cited 2016 Juni. 5]. Available from: URL: http://.www.who.int/ water_sanitation_health/ publications/ 2011/ dwq_chapters/ en/\&usg. 